and, indeed, it is not easy to elaborate the bare list of subjects without transgressing the limits set. But mention must be made of one point that emerged during the symposium, namely, the great promise that is held for the advancement of glacier physics. This has been perhaps the chief interest of the British glaciologists since Forbes and Tyndall, and later Deeley and Tutton, carried out their quests in the Alps. There has now been formed a Glacier Physies Committee on the initiative of Dr. M. F. Perutz of the Cavendish Laboratory and under the chairmanship of the Society's President. Several distinguished men of science have joined it in order to give assistance in subjects not normally part of glaciology but which will profoundly affect the course of the contemplated research.

The Glacier Physics Committee is in contact with Swiss glaciologists, and this combination should be able to make important advances in their main theme - the mechanism of glacier flow. This has been a source of controversy for nearly two and a half centuries and, although the subject of much research and a good deal more speculation, there has never been a really well organised, systematic attack on the problem. It is not only of pure glaciological interest; it has been pointed out that a flowing glacier may be likened to a greatly accelerated rock mass in process of translation and recrystallization, and there are other obvious analogies, especially in metallurgy, to the behaviour of ice under stress.

It is only possible to single out two other points upon which discussion centred, namely, the climatological factors touched on above and the movement of the pack ice, so important for whaling and for shipping generally.

The wide field covered by the word 'glaciology' has had many brilliant exponents in Great Britain, but it cannot be said that there has been a regular school of research as there has been in other countries. It was not until after the meeting of the International Union of Geodesy and Geophysics in Edinburgh in 1936 that an atmosphere of continuity began. Since then, except for the war years, interest has increased steadily, and the science now seems to be on a firm basis and the course set for intensive work.

The full report of the meeting will be published in the Society's Journal of Glaciology. A detailed exposition of the programme proposed for the Glacier Physics Committee will be found in the Journal of Glaciology, Vol. 1, No. 2, pp. 45-51.

\section{RECENT RESEARCH ON LOCUSTS}

T HE establishment of the Anti-Locust Research Centre at the British Museum (Natural History) marks an important step in solving problems of locust control. One of the main functions of that organisation has been the assembling and recording of reports on the breeding and migrations of locusts in Africa and Western Asia. No fewer than 7,986 reports have been received from the Governments of the territories in these areas up to the end of 1945. The collation and sifting of the data thus acquired entails a large amount of detailed work, which is ultimately incor. porated in the publications of the Anti-Locust Centre. These latter are planned in two series. First, memoirs of quarto size adapted for the publication of detailed charts, etc., devoted to biogeographical and bioclimatic papers; secondly, bulletins intended for the publication of papers on all other aspects of locust and grasshopper research and control. Up to date, two memoirs have appeared and a third is in the press. The first of the bulletins is also in the press.

Anti-Locust Memoir 1, by Z. Waloff, is entitled "Seasonal Breeding and Migrations of the Desert Locust (Schistocerca gregaria) in Eastern Africa" (1946; 76 pp., 30 maps)*. The primary purpose of this study was to analyse and describe the seasonal breeding and migrations of the swarms of this locust in the East African area. The material used to form the basis of this study was the data relating to an outbreak of this insect lasting from 1928 until 1931, and to the outbreak from August 1941 to February 1945. It appears that there is no inherent urge on the part of this locust to migrate in any particular direction or to search for suitable breeding grounds. The major trends of migrations are down the prevailing winds and change with them: old mature swarms, however, tend to fly against the wind. The distribution of the swarms in any season is largely dependent on the pattern of the air temperatures and winds. The incidence of breeding depends, among other factors, on the incidence of suitable rainfall conditions. Because of this, and of the mobility of swarms, the location of breeding areas is not constant but follows seasonal fluctuations of rainfall.

Anti-Locust Memoir 2 is by Miss V. Morant, and is entitled "Migrations and Breeding of the Red Locust (Nomadacris septemfasciata) in Africa, 1927-1945" (1947 ; 60 pp., 32 maps). The outbreak considered in this memoir lasted from 1927 until 1944, a period of more than eighteen years, during which time swarms were recorded from the Anglo-Egyptian Sudan and British Somaliland southwards to the Union of South Africa. In other words, the whole of Africa south of the equator was infested at some time or another during this outbreak, excepting certain coastal areas and the Equatorial Rain-Forest Belt in the north. The greater part of the material used in this study was derived from monthly reports sent to the Anti-Locust Centre from the various countries that were invaded during the outbreak. No fewer than 23,270 records of swarms have been received at this Centre, which enabled the application of cartographical methods to obtain a more complete picture of the rise and decline of the outbreak than has been previously available for any locust.

This same species of locust also forms the subject of an extensive paper by A. P. G. Michelmore in the Bulletin of Entomological Research (37, pt. 3, 331; 1947), and entitled "The Habits and Control of the Red Locust in Outbreak Areas and Elsewhere". The last great invasion of this insect started almost certainly from two restricted areas only, namely, the Mwera Marsh in the extreme north of Northern Rhodesia and Lake Rukwa in the south-west of Tanganyika Territory. The regular and constant observation of these areas is of prime importance, in that it enables incipient swarms to be destroyed, as happened in the rainy seasons of 1942-43 and 1943-44. At present, the best method of control in widespread campaigns is arsenical baiting. It is hoped, however, that insecticidal dusting from aeroplanes will soon be possible. The use of arsenicals puts certain limitations on campaigns on account of their danger to

\footnotetext{
* Copies available to institutions and persons engaged in locust and grasshopper research, in exchange for their publications. Request to be addressed to the Director, Anti-Locust Research Centre, British Museum (Natural History), London, S.W.7. Also obtainable from "The Times" Printing Works, Richmond, Surrey. Memoir 1, 88.
} post paid; Memoir 2 68. post paid. 
man and stock, and the expense entailed owing to the need for close European or other reliable supervision. The author stresses the need for discovering less dangerous compounds both for terrestrial and aerial methods of control. He discusses the habits of the red locust in detail and stresses the importance of preventing outbreaks by controlling them at the source. The possibility of making these areas unsuitable for the species is also discussed. In this connexion draining, flooding and the prevention of grass fires are possible in some areas but not in others.

A. D. TMMs

\section{FORTHCOMING EVENTS}

(Meeting marked with an asterisk * is open to the public)

Monday, July 14-Thursday, July 17

Chemical Society (in London).--Centenary Celebrations.

Monday, July 14

At the Science Museum, South Kensington, London, S.W.7.Opening of the Centenary Exhibition by Prof.'C. N. Hinshelwood, F.R.S.

Tuesday, July 15

At the Central Hall, Westminster, London, S.W.1.-Reception by the President and Council; Prof. C. N.'Hinshelwood, F.R.S.: Centenary Address.

Wednesday, July 16

At the Royal Institution, Albemarle Street, London, W.1.--Prof E. K. Rideal, F.R.S.: "The Work of the Royal'Institution in Physical Chemistry in Great Britain".

At the Institution of Civil Engineers, Great George Street, London, S.W.1.-Prof. J. Read, F.R.S.: "Chemical Personalities a Century Ago:

At the Central Hall, Westminster, London, S.W.1.-Sir Robert Robinson, P.R.S.: The Faraday Lecture.

Monday, July 14-Saturday, July 19

SOUTh EASTERN UNION OF SCIENTIFIC SOcteties (in the Royal Pavilion, Brighton).-Fifty-first Annual Congress.

Tuesday, July 15

At 8 p.m.-Prof. W. A. F. Balfour-Browne: "The Possibilities of Natural History" (Presidential Address).

Thursday, July 17 At 8 p.m. - Film : "The Beginning of History", with Introductory
Lecture by Dr. E. Cecil Curwen.*

Friday, July: 18

At 10 a.m.-Discussion on "The Place of Scientiflc Societies in the Promotion of Science".

\section{Thursday, July 17}

BRITISH INSTITUTE OF RADIOLOGY (in the Reid-Knox Hall, 32 Welbeck Street, London, W.1) at 8 p.m.-Dr. John H. Lawrence (University of California): "The Application of Artiflcial Radioactivity to Biology and Medicine" (Twenty-fourth Mackenzie Davidson Memorial Lecture).

Thursday, July 17-Thursday, July 24

XIth INTERNational Congress OF PURE AND APPLied Chemistry (in London).

Thursday, July 17

At 10.30 a.m. (at Central Hall, Westminster, London, S.W.1).Opening Ceremony by Lord Leverhulme; at 2.30 p.m. (at the Imperial college of Science and 'Technology, South Kensington, London, S.W.7). College of Science and Technology, south

Friday, July 18

At 2.30 p.m. (at the Imperial College of Science and Technology, South Kensington, London, S.W.7).--Sir Henry Dale, O.M., F.R.S. Congress Lecture.

Tuesday, July 22

At 2.30 p.m. (at the Imperial College of Science and Technology, South Kensington, London, S.W.7).- Prof. I. Hackspill: Congress Lecture.

Thursday, July 24

At 10.30 a.m. (at Central Hall, Westminster, London, S.W.1).Lecture by Sir Robert Robinson, P.R.S.

Friday, July 18 -Saturday, July 19

Institure of Physics, Indostrial Radiology Group (at the Electric Lamp Manufacturers' Association, 2 Savoy Hill, London, W.C.2).-Symposium on "Methods of Crack Detection".
Friday, July 18

At 10 a.m.-Dr. W. Betteridge : Introductory Address ; Papers on "Radiological Methods" and "Visual, Etching and Magnetic Methods" Saturday, July 19

At 9.30 a.m.-Annual General Meeting of the Group; at 10 a.m.Papers on "Eddy-current Methods" and "Crack Detection by Supersonic Methods".

\section{APPOINTMENTS VACANT}

APPLICATIONS are invited for the following appointments on or before the dates mentioned

LECTURER IN PHYSIOLOGY-The Dean, Medical College of St. Bartholomew's Hospital, West Smithfleld, London, E.C.1 (July 18). TEACHER OF BIOLOGY to Inter.B.Sc. standard at the Coventry
TechnicalCollege-The Director of Education, Council House, Coventry Technical

ENGINEer IN THE AUdIo Frequency Section of the Research Department based in London-The Engineering Establishment Officer, British Broadcasting Corporation, Broadcasting House, London, W.1 (July 19).

LieOTURER IN MEChanical ENGINEERING-The Clerk to the Govermors, Heanor Technical Institute, Heanor, Nottingham (July 19). SECRETARY to the recently created Institute of Education
Secretary and Registrar, The University, Bristol (July 20).

ZOOLOGIST or ENTOMOLOGIST (male) for studies on the fauna of forest soils in relation to fertility - The Secretary, Rothamsted Experimental Station, Harpenden, Herts. (July 26).

AssistaNT LECTURER IN GEOLOGY-The Registrar, The University, Manchester 13 (July 26).

ASSISTANT LECTURER IN PURE Mathematios-The Registrar, University College, Singleton Park, Swansea (July 26).

SENIOR ASSISTANT TEACHER IN THE MECHANICAL ENGINEERING DEPARTMENT-The Secretary, South-East London Technical Institute, Lewisham Way, London, S.E.4 (July 26).

SENIOR LECTURER IN ACCOUNTING in the University of the Witwatersrand, Johannesburg-The Secretary, Universities Bureau of the British Empire, 8 Park Street, London, W.1 (July 30).

SENIOR LECTURER IN ORGANIC CHEMISTRY, and a SENIOR LECTURER IN INORGANIC AND ANALYTICAL CHEMISTRY, in the Rhodes University College, Grahamstown-The Secretary, Office of the High Commissioner
for the Union of South Africa, Trafalgar Square, London, W.C.2 (July 31).

LECTURER IN THE DEPARTMENT OF GEOXOGY-The Secretary, The University, Aberdeen (July 31).

Laboratory TeChNician in the Department of PhysiologyThe Registrar, The University, Liverpool (August 1)

LABORATORY ASSISTANT IN THE PATHOLOGICAL UNIT at the Barking Hospital-The Town Clerk, Town Hall, Barking, Essex, endorsed 'Laboratory Assistant' (August 15).

SENIOR PRINCIPAL SCIENTIFIC OFFICER in the Ministry of Supply at the Chemical Research and Development Department, Waltham Abbey-The Secretary, Civil Service Commission, 6 'Burlington Gardens, London, W.1, quoting No. 1937 (August 15).

SENIOR PRINCIPAL SOIENTIVIC OFFICER to take charge of research SENIOK Pon and development work on aircraft fire control equipment in the borough-The Secretary, Civil Service Commission, 6 Burlington Gardens, London, W.1, quoting No. 1938 (August 15).

Gardens, London, w.1, quoting No. 1938 (August 15). LECTURER IN ELECTRICAL ENGINEERING in the University of Cape 8 Park Street, London, W.1 (August 21).

8 Park Street, London, W.1 (August 21). Technical College, Salford 5 (August 23).

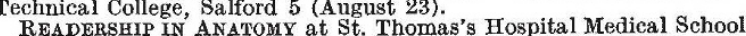
.The Academic Registrar, University of London, Senate House, London, W.C.1 (August 26).

RESEARCH STATISTICIAN, an ASSISTANT STATISTICIAN, and a MATHXMATIOAL COMPUTER-The Secretary, Rothamsted Experimental Station, Harpenden, Herts.

LEOTURER IN THE SCIENCE AND TECHNOLOGY OF REFRIGRRATION to the standard of the City and Guilds syllabus-The Hon. Secretary, to the standard of the City and Guilds syllabus-The Hon. Secretary, Institute of Kon, E.C.1.

London, E.C.1. Research in the Department of Collond ScrencF ASSISTANT IN RESEARCH IN THE DEPARTMENT OF CoLloID Scrence

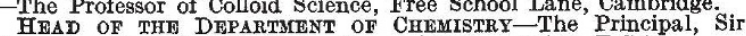
Hohn OF THE DEPARTALNT OF CHEMISTRY-The Principal,

LECTURER IN BACTERIOLOGY-The Secretary, King's College of LECTURER IN BACTERIOLOGY-The Secretary, King's College Sinior MINING GEoLoGIST-The Secretary, Mianrai, Teoranta, Sinior MINING GEOLOGIST-The Secretary,
Four Provinces House, Harcourt Strcet, Dublin

Four Provinces House, Harcourt Strcet, Dublin. LECTURER IN IMPLEMENTS AND MACHINERY in the Faculty of Agri-
culture and Horticulture-The Registrar, The University, Reading. culture and Horticulture-The Registrar, The University, Reading.
Professor OF PHYSICAL METALLURGY-The Dean, Faculty of Applied Science, University of Toronto, Toronto, Ont., Canada.

LECTURER IN GEOGRAPHY in the University of Otago, DunedinThe High Commissioner for New Zealand, 415 Strand, London, W.C.2. IECTURER IN PHYSIOLOGY AND ZOOLOGY-The Registrar, Technical College, Sunderland.

SENIOR ASSISTANT, and a LECTURER, with special responsibility, in Mechanical and Proddction Enaineering, and Assistants with qualifications in Mathematics and Physics and/or Engineering Drawing and Engineering Science--The Principal, Technical College, Walsall. SENIOR ASSISTANT IN ELECTRICAL ENGINEERING, specializing in Design of Electrical Machinery, a LECTURER IN MECHA NIOAL ENGINERRING to Degree and Higher National Certificate students, and a LECTURER IN MATHEMATICS mainly to National Certiflcate students-The Principal, College of Technology and Arts, Rugby.

PROFESSOR OF CHEMISTRY, a PROFESSOR OF BOTANY, a PROFESSOR OF ZOOLOGY, and a SENIOR LECTURER IN PHYSICS, in the University College of the West Indies-The Secretary, Inter-University Counci for Higher Education in the Colonies, 8 Park Street, London, W.1. 